\title{
Micromonospora brunnea Sveshnikova, Maksimova, and Kudrina 1969 is a Junior Subjective Synonym of Micromonospora purpureochromogenes (Waksman and Curtis 1916) Luedemann 1971
}

\author{
ZSUZSA SZABÓ* AND C. FERNANDEZ \\ Department of Microbiology, Eötvös L. University, Budapest, Hungary
}

\begin{abstract}
The characteristics of the type strains of Micromonospora brunnea and Micromonospora purpureochromogenes were compared. The high degree of similarity obtained suggests that these two species should be amalgamated under the name Micromonospora purpureochromogenes (Waksman and Curtis 1916) Luedemann 1971 and that Micromonospora brunnea should be regarded as a later subjective synonym.
\end{abstract}

The Approved Lists of Bacterial Names (11) contained 12 species of the genus Micromonospora, including both Micromonospora brunnea and Micromonospora purpureochromogenes. M. brunnea was described by Sveshnikova et al. first in Russian (13) and later in English (14). The combination Micromonospora purpureochromogenes was proposed by Luedemann (9), because the type strain of Streptomyces purpureochromogenes (strain IMRU 3343) proved to be a Micromonospora, and it was therefore transferred to the genus Micromonospora as $M$. purpureochromogenes (Waksman and Curtis 1916) comb. nov. At the same time, Micromonospora fusca Jensen 1932 was regarded by Luedemann as a subjective synonym of $M$. purpureochromogenes.

In this paper, we compare the type strains of $M$. brunnea and $M$. purpureochromogenes on the basis of a number of morphological, cultural, and physiological characteristics and propose a formal statement on the nomenclature of these organisms.

\section{MATERIALS AND METHODS}

Bacterial strains. The following strains were compared: $M$. purpureochromogenes ATCC $27007^{\mathrm{T}}(\mathrm{T}=$ type strain) and $M$. brunnea ATCC $27334^{\mathrm{T}}$. Working cultures were maintained on yeast extract-starch agar (9).

Micromorphological characterization. Microscopic morphology was studied in yeast extract-glucose liquid medium and in yeast extract-starch agar slide cultures. Observations were made daily from 3 to 14 days of incubation.

Cultural characterization. Cultural properties were observed on the following International Streptomyces Project (ISP) media: yeast extract-malt extract agar, inorganic saltsstarch agar, and glycerol-asparagine agar (10). In addition, Czapek-sucrose agar, glucose-asparagine agar, tyrosine agar (17), and peptone-iron agar (Difco Laboratories, Detroit, Mich.) were used. Inoculated plates were incubated for 2 weeks at $28^{\circ} \mathrm{C}$.

Physiological and biochemical tests. Carbon source utilization, $\mathrm{NaCl}$ tolerance, and potato plug acidity tolerance tests were performed by the method of Luedemann (9). Utilization of amino acids as carbon and nitrogen sources was tested in basal medium containing $1 \mathrm{~g}$ of yeast extract, $1 \mathrm{~g}$ of $\mathrm{CaCO}_{3}, 15 \mathrm{~g}$ of agar, and $1,000 \mathrm{ml}$ of distilled water. Utilization of other $\mathrm{N}$ compounds was examined in medium containing $10 \mathrm{~g}$ of glucose, $1 \mathrm{~g}$ of yeast extract, $1 \mathrm{~g}$ of $\mathrm{CaCO}_{3}$, $15 \mathrm{~g}$ of agar, and $1,000 \mathrm{ml}$ of distilled water. $\mathrm{N}$ compounds were added to final concentrations of $280 \mathrm{mg}$ of nitrogen per liter (15). The temperature range for growth was detected on yeast extract-starch agar (9). Cellulose decomposition was

\footnotetext{
* Corresponding author.
}

observed in tubes containing $5 \mathrm{ml}$ of Luedemann liquid basal medium (9) with a filter paper strip after 1 month of incubation. Milk digestion was tested as described by Luedemann (9), except that basal medium and reconstituted skim milk (Difco) were mixed at a ratio of $2: 1$. Nitrate reduction was determined both in nitrate broth (Difco) and in Luedemann glucose-nitrate broth (9). Utilization of organic acids was tested by the method of Gordon (4). Tests for decomposition of allantoin, arylsulfatase activity, and tellurite reduction were performed by using the methods described by Kurup and Schmitt (7), partly modified. Hydrolysis of hippurate and sensitivity to sodium salicylate were examined by the methods of Gordon and Horan (5). For detection of esculin and arbutin hydrolysis, these compounds were added to the broth of Cowan and Steel (2) at final concentrations of $0.1 \%(\mathrm{wt} / \mathrm{vol})$. Hydrolysis of nucleic acids was determined by the method of Jeffries et al. (6). Urease activity was detected by using the medium of Christensen (1). The method of Cowan and Steel (2) was used to detect phosphatase activity. Hydrolysis of starch was observed on starch-peptone-meat extract agar (16). Hydrolysis of tributyrin was determined on medium containing $10 \mathrm{~g}$ of glucose, $10 \mathrm{~g}$ of yeast extract, $10 \mathrm{~g}$ of glycerol tributyrate, 15 $\mathrm{g}$ of agar, and 1,000 ml of distilled water $(\mathrm{pH} \mathrm{7.0)}$. Alginate hydrolysis was detected by using the method of Davis and Ewing (3). Susceptibility to antibiotics and antimicrobial agents was tested on starch-nutrient agar plates inoculated with dense spore suspensions. Resistest susceptibility disks (Human, Budapest, Hungary) were used.

\section{RESULTS AND DISCUSSION}

The characteristics shared by both type strains are listed below.

Spores occurred on the chiefly monopodially branching hyphae singly or in clusters. The mature spores were spherical and approximately $1.0 \mu \mathrm{m}$ in diameter, with rough surfaces.

Growth was good on yeast extract-malt extract agar (ISP medium 2), fair to good on inorganic salts-starch agar (ISP medium 4), and glycerol-asparagine agar (ISP medium 5), and poor to fair on Czapek-sucrose agar and glucoseasparagine agar. Colonies were usually folded and orange to brown or dark brown to black. Brown or dark brown soluble pigments were produced in most media. Melanoid pigments were not observed in tyrosine and peptone-iron agar media.

D-Xylose, D-fructose, D-galactose, D-glucose, mannose, cellobiose, $\beta$-lactose, maltose, $\alpha$-melibiose, sucrose, raffinose, dextrin, inulin, and glycerol were utilized, but Larabinose, L-rhamnose, sorbose, trehalose, L-melezitose, $\alpha$ methyl-D-glycoside, salicin, and i-inositol were not. Good 
growth occurred with acetate and pyruvate as sole sources of carbon, with a color change in the medium due to changed $\mathrm{pH}$ values. No or only traces of growth and color change occurred with benzoate, citrate, and oxalate. DL-Phenylalanine was utilized as both carbon and nitrogen sources, but DL-alanine, L-tryptophan, L-glutamic acid, L-lysine, L-asparagine, L-arginine, L-histidine, and L-cystine were not. DLAlanine, L-asparagine, $\mathrm{L}$-arginine, $\mathrm{NaNO}_{3}$, and $\mathrm{KNO}_{3}$ were utilized as nitrogen sources, but DL-phenylalanine, L-tryptophan, L-glutamic acid, L-lysine, L-histidine, L-cystine, and $\left(\mathrm{NH}_{4}\right)_{2} \mathrm{SO}_{4}$ were not. Starch, esculin, and tributyrin were hydrolyzed, but alginate, allantoin, arbutin, cellulose, and hippurate were not. The strains did not digest milk or digested it only extremely slowly. Phosphatase, deoxyribonuclease, and ribonuclease were produced, but arylsulfatase and urease were not. Tests for sensitivity to salicylate and tellurite reduction were positive. Growth on potato slices with and without calcium carbonate was good. Growth was reduced in the presence of $2 \% \mathrm{NaCl}$ and did not occur in the presence of $3 \% \mathrm{NaCl}$. Growth was good at $6^{\circ} \mathrm{C}$ and poor at $40^{\circ} \mathrm{C}$. No growth occurred at 0,45 , and $50^{\circ} \mathrm{C}$. Both strains were resistant to superseptyl $(400 \mu \mathrm{g})$, nitrofurantoin $(300$ $\mu \mathrm{g})$, nalidixic acid $(30 \mu \mathrm{g})$, nystatin (100 IU), and sumetrolim $(25 \mu \mathrm{g})$, but moderately or strongly susceptible to penicillin (3 IU), oxacillin $(10 \mu \mathrm{g})$, methicillin $(20 \mu \mathrm{g})$, chloramphenicol $(30 \mu \mathrm{g})$, oleandomycin $(30 \mu \mathrm{g})$, streptomycin $(30 \mu \mathrm{g})$, tetracycline $(30 \mu \mathrm{g})$, neomycin $(100 \mu \mathrm{g})$, erythromycin $(10 \mu \mathrm{g})$, polymyxin $\mathrm{B}(15 \mu \mathrm{g})$, chlortetracycline $(30 \mu \mathrm{g})$, oxytetracycline $(30 \mu \mathrm{g})$, vancomycin $(50 \mu \mathrm{g})$, kanamycin $(30 \mu \mathrm{g})$, spiramycin $(30 \mu \mathrm{g})$, ampicillin $(20 \mu \mathrm{g})$, lincomycin $(10 \mu \mathrm{g})$, cephalosporin $(10 \mu \mathrm{g})$, pristinamycin $(10 \mu \mathrm{g})$, paromomycin $(50 \mu \mathrm{g})$, gentamicin $(20 \mu \mathrm{g})$, and carbenicillin $(50 \mu \mathrm{g})$.

Noticeable differences between the two type strains occurred only in nitrate reduction and susceptibility to colistin. Thus, in contrast to $M$. purpureochromogenes ATCC $27007^{\mathrm{T}}, M$. brunnea ATCC $27334^{\mathrm{T}}$ reduced nitrate to nitrite, but the latter was susceptible to colistin $(20 \mu \mathrm{g})$, whereas strain ATCC $27007^{\mathrm{T}}$ was not. The percentage of similarity according to the coefficient of Sokal and Michener (12) between these two strains on the basis of 172 diagnostic features was $94.2 \%$, indicating that they should be regarded as members of the same species.

Our test results clearly demonstrate that the classification of the two type strains as representative members of two different species cannot be justified. On the basis of priority, according to the rules of the International Code of Nomenclature of Bacteria (8), the name $M$. purpureochromogenes must be retained for this species. Previously, "M. fusca" was regarded as a subjective synonym of $M$. purpureochromogenes (9). We propose that $M$. brunnea should be considered another subjective synonym of $M$. purpureochromogenes.

\section{LITERATURE CITED}

1. Christensen, W. B. 1946. Urea decomposition as a means of differentiating Proteus and paracolon cultures from each other and from Salmonella and Shigella types. J. Bacteriol. 52:461466.

2. Cowan, S. T., and K. J. Steel. 1965. Manual for the identification of medical bacteria. Cambridge University Press, Cambridge.

3. Davis, B. R., and W. H. Ewing. 1964. Lipolytic, pectolytic, and alginolytic activities of Enterobacteriaceae. J. Bacteriol. 88:1619.

4. Gordon, R. E. 1968. The taxonomy of soil bacteria, p. 293-321. In T. R. G. Gray and D. Parkinson (ed.), The ecology of soil bacteria. Liverpool University Press, Liverpool.

5. Gordon, R. E., and A. C. Horan. 1968. A piecemeal description of Streptomyces griseus (Krainsky) Waksman and Henrici. J. Gen. Microbiol. 50:223-233.

6. Jeffries, C. D., D. F. Holtman, and D. G. Guse. 1957. Rapid method for determining the activity of microorganisms on nucleic acids. J. Bacteriol. 73:590-591.

7. Kurup, P. V., and J. A. Schmitt. 1973. Numerical taxonomy of Nocardia. Can. J. Microbiol. 19:1035-1048.

8. Lapage, S. P., P. H. A. Sneath, E. F. Lessel, V. B. D. Skerman, H. P. R. Seeliger, and W. A. Clark (ed.). 1975. International code of nomenclature of bacteria. 1975 Revision. American Society for Microbiology, Washington, D.C.

9. Luedemann, G. M. 1971. Micromonospora purpureochromogenes (Waksman and Curtis 1916) comb. nov. (subjective synonym: Micromonospora fusca Jensen 1932). Int. J. Syst. Bacteriol. 21:240-247.

10. Shirling, E. B., and D. Gottlieb. 1966. Methods for characterization of Streptomyces species. Int. J. Syst. Bacteriol. 16:313340.

11. Skerman, V. B. D., V. McGowan, and P. H. A. Sneath (ed.). 1980. Approved lists of bacterial names. Int. J. Syst. Bacteriol. 30:225-420.

12. Sokal, R. R., and C. D. Michener. 1958. A statistical method for evaluating systematic relationships. Univ. Kans. Sci. Bull. 38:1409-1438.

13. Sveshnikova, M. A., T. S. Maximova, and E. S. Kudrina. 1969. The species belonging to the genus Micromonospora Oerskov, 1923 and their taxonomy. Mikrobiologiya 38:883-893. (In Russian.)

14. Sveshnikova, M., T. Maximova, and E. Kudrina. 1970. Species of the genus Micromonospora Ørskov, 1923 and their taxonomy, p. 187-197. In H. Prauser (ed.), The Actinomycetales. The Jena International Symposium on Taxonomy. Gustav Fischer Verlag, Jena.

15. Szabó, I. M. 1974. Microbial communities in a forest-rendzina ecosystem. The pattern of microbial communities. Akadémiai Kiadó, Budapest.

16. Szabó, I. M., M. Marton, G. Kulcsár, and I. Buti. 1976. The taxonomy of primicin producing actinomycetes. I. Description of the type strain of Thermomonospora galeriensis. Acta Microbiol. Acad. Sci. Hung. 23:371-376.

17. Waksman, S. A. 1961. The actinomycetes, vol. 2. Classification, identification and description of genera and species. The Williams \& Wilkins Co., Baltimore. 